\title{
Challenges of the Automobile Industry and Performance Analysis of an Assembly Plant in Nigeria
}

\author{
Paul Tamaragaibi Elijah ${ }^{1 *}$, Nnamdi Chukwuemeka Ezeife ${ }^{2}$ \\ ${ }^{1}$ Applied Mechanics and Design/Production Research Group, Department of Mechanical Engineering, Nigeria Maritime University, Okerenkoko, Delta \\ State, Nigeria \\ ${ }^{1,2}$ Department of Mechanical Engineering, University of Port Harcourt, Choba, Port Harcourt, Rivers State, Nigeria
}

DOI: $\underline{10.36348 / \text { sjet.2020.v05i09.003 }}$ | Received: 06.09.2020 | Accepted: 14.09.2020 | Published: 17.09 .2020

*Corresponding author: Paul Tamaragaibi Elijah

\section{Abstract}

This study looked at the challenges faced by the automobile industry in Nigeria. The study also carried out automotive assembly process performance analysis for improved productivity. The analysis was performed at an automobile plant in Nigeria. The overall number of material handling systems and kinds of material handling systems were determined. The number of automated, manual and semi-automated equipment's used was also determined. The number of workers on the line were also determined. The labour productivity, hours per unit, organizational hour per unit, and TEEP were also determined. From the analysis, the average production volume of automobile assembly line is 256 units for every month and its average on time delivery is $80.6 \%$. Nine hours was the time period the workers spent every day. 163 personnel with various skill sets were involved in the plant. The size of the plant is about $550,000 \mathrm{~m}^{2}$ and it housed offices, workstations, equipment's and operators. The average hour per unit is 155 hours. The average organizational hour per unit is 148 hours i.e. it takes 148 hours to assemble the car. The total effective equipment performance is $61.89 \%$. This result shows that the plant is still under-utilized. The study recommends that more workers should be employed and predictive maintenance practises should be used to avoid collapse of machines in the assembly plant.

Keywords: Automobile industry, Challenges, Equipment performance, Performance analysis, Nigeria.

Copyright @ 2020: This is an open-access article distributed under the terms of the Creative Commons Attribution license which permits unrestricted use, distribution, and reproduction in any medium for non-commercial use (NonCommercial, or CC-BY-NC) provided the original author and source are credited.

\section{INTRODUCTION}

There are numerous trials that have befallen the Vehicle industries in Nigeria. Automobile industries created in Nigeria are concentrated on policy. In 1994, a law was enacted by government to defend and buy automobiles made in Nigeria, which says government must purchase every of their car from within the country unless when the vehicle is unavailable domestically. The government established this law to help support and defend indigenous automobile industries, but this law has been strapped aside by government itself. Foreign made automobiles are being bought by the Nigeria government rather than patronizing the ones produced locally.

Decades later, the government is not concerned in the improvement of technical abilities amongst their citizen. The government trusts that with its natural gifts which is basically crude oil, the country will be unable to face any economic challenge but previous front runners of Nigeria has wasted the reserve of the land by embezzling money overseas, building companies and houses rather than spending the money on domestic industries in the state that will aid improve production and also create lots of job chances for their citizens. Dr. Oscar Odiboh, who is a consultant in the automobile sector, specified that all technologically advanced economies of a country only rest on a working automotive organization [1].

In Nigeria, when you purchase a brand firsthand vehicle, the interest rate is actually much; buying a vehicle in Nigeria is actually expensive, such that persons from the average class in Nigeria cannot afford to acquire a vehicle of their choice. This is as a result of cost facing these auto companies in manufacturing these automobiles. Russia and India try to significantly cut interest amount on loan for vehicle purchase by $5 \%$ when acquiring cars, to encourage their domestic industries by significantly cutting tariff meant for quota of automotive sectors.

The fee and upkeep of automobile vehicles in Nigeria is expensive due to the state of the economy. Being a car owner is quiet a huge feat in Nigeria. 
Someone who purchases a car in Nigeria is seen as aclue that suffering has been eradicated. Buying of an automobile and a house is celebrated with great joy which is seen almost equally as the birth of a boy in a typical Nigerian Family. This automobiles are not even marque first hand cars, but cars imported as fairly used, commonly called Tokunbo [2].

A man is presumed to have being made when he acquires a marque first hand car. Immediately a fellow buys a marque first hand car, he is said to have succeeded. Parties are thrown, neighbors are invited, even the adversaries are mocked prayerfully, having lost the fight for the reason that he has bought a car. Poor economy caused all these. People no longer acquire marque first hand vehicles since the economy of the land is influential on the wellbeing of its citizens and this basically tells on the victory story of car sector Nigeria.

The owners of companies are the individuals who bear the expenses of operating vehicle industries in Nigeria. The atmosphere is not conducive for existing companies, as the Nigeria government can never strategize ways to back the surviving companies instead they look for ways to exploit the organizations by raising tariffs annually and invariably asking them to pay for their existence. The boss of a newspaper company in Nigeria, Odiboh says that a state that is technologically advanced has a vehicle industry working [1]. Government has failed in providing fund for the car sector in Nigeria; absence of cash is disturbing plenty of the automobile sectors in the nation.

Electricity is the regulator of every industry in established industries. Power shortage is as result of company not growing relative to enhancement and growth. Overseas, most developed countries are skilled instanding test of time based on steady transmission of power basically applied to operate their machines. Nigerian Automobile industries can only stand the test of time once there is continuous distribution of electricity. The expense of buying petroleum to drive power plants during manufacturing and price of upkeep of power plant is expensive. Many automobile companies in Nigeria are hard done as a result of their financial state which results in low production.

In this paper, the performance of an automotive assembly plant was analyzed. Some of the parameters evaluated include: Labour number, Material Handling Equipment, Number of Equipment, Hour per unit, Organization hour per unit, etc. The aim of the work is to discover alternative ways or techniques to increase the throughput of an automotive assembly process or plant in Nigeria by performance analysis.

\section{METHODOLOGY}

Verbal discussions with production managers, supervisors, and operators of an automobile company was used in data collection in this study. Timing equipment and physical surveillance of the processes was also used in the study. Performance parameters of some work stations that included machine productivity and manpower productivity were measured in order to evaluate the performance of the automobile company. To calculate the percentage of assembled products produced every month that is on time delivery and the work in process, a performance analysis was done. Below are the performance parameters evaluated.

\section{Material Handling Equipment}

Material handling equipment's consists of machines used in the automotive sector to convey material starting from one workstation to another. Overall number of material handling equipment for every work location in the plant for six months is made available in the next section.

\section{Workshop Machinery}

Workshop Machinery in the plant is the equipment basically used to perform automobile assembly operations. This equipment may be automated, semi-automated or manual. The number of automated, semi-automated, and manual machines meant for every single work station is as shown in the result section.

\section{Number of Workers for each station in the Assembly Line}

In assembly line, the number of technicians, engineers, and helpers for the various sections are shown in the result section. It is also given that the working time every day is 9 hours. Total number of workforces for every station is also provided in the result section

\section{Organizational Hours per Unit (OHPU)}

OHPU is defined as a key performance indicator for workforce performance meant for benchmarking amongst different plants of the industrial sector. Organizational Hours per Unit can also be defined as the ratio of actual operational hours of every worker in an organization and production volume within a definite time. It is calculated every month. OHPU values calculations are not just done for only the factory in general, but it is as well calculated in detail for every single product and every Organizational unit, such as organization structure, essential business regions, key assemblage regions and workforce types.

It is from the Payroll, employees working in the organization, short-term workforces, and external upkeep services that we get total working hours:

Let $\mathrm{Y}=$ total working hours of every worker of the organization in a month in hours

$\mathrm{y}_{\mathrm{b}}=$ total working time of workers in body shop section 
$\mathrm{y}_{\mathrm{p}}=$ total working time of workers in paint shop section for a month in hours

$\mathrm{y}_{\mathrm{t}}=$ total working time of workers in trim chassis final for a month in hours

$\mathrm{P}=$ Production volume for a month in units/month Therefore;

$$
\begin{gathered}
Y=\sum\left(y_{B}+y_{p}+y_{t}\right) \ldots \\
P=\sum(w 1+w 2+w 3)
\end{gathered}
$$

Where,

$$
\begin{gathered}
\text { w1 }=\text { week one } \\
\text { w2 }=\text { week two } \\
\text { w3 = week three } \\
\text { OHPU }=\frac{Y}{P} \\
\text { OHPU }=\frac{\sum\left(y_{b}+y_{p}+y_{t}\right) \text { hours }}{\sum(w i+w 2+w 3) \text { units }} .
\end{gathered}
$$

\section{Hours per Unit (HPU)}

Hours per Unit are key performance indicators that convert the number of hours necessary to construct a vehicle. It is calculated for a particular time as well as for a precise model. Hour per unit is similar to Organizational hour per unit, but it has to do with workers connected with manufacturing process.

It is achieved by using the ensuing formula:

$$
\mathrm{HPU}=\frac{M \cdot A \cdot \times E \cdot W \cdot T}{\text { production volume }}\left(\frac{\text { hours }}{\text { unit }}\right)
$$

Where,

M.A. = Manpower working in the assembly line

E.W.T. $=$ Effective working time

\section{Availability}

The percentage of manufacturing time machinery is operating to manufacturing time the machinery is obtainable (that is overall runtime of machinery deducting all unforeseen interruption) is known as availability of machinery. Availability considers all activities that halted intended production long sufficient where it makes common sense to find a genuine reason for the machinery being down.

Availability $=\frac{\text { Actual production Time }}{\text { planned production Time }}$

\section{Quality}

The quality of products is percentage of good items to total items assembled in an automotive plant. Quality considers manufactured parts which are not up to quality standard together with parts that have need of rework.

Quality $=\frac{\text { Total products produced }- \text { Number of rejected }}{\text { Total Quantity Produced }}$

\section{Total Effective Equipment Performance (TEEP)}

TEEP is used for analysis of capacity utilization. Total effective equipment performance is being determined weekly. TEEP is basically a performance metric responsible for providing insights towards the exact capacity of assembly processes. TEEP shows just how much capacity is still waiting to be cracked in a secret plant. Furthermore, it displays exactly how much potential you need to improve the rate of production by using current equipment you are making use of. As we have seen from several instances, recovering time from your concealed plant is a quicker and less costly substitute to acquiring first-hand equipment. TEEP can as well be used to have an idea of your possible sales capability as it considers the entire capacity of that your production plant.

$$
\mathrm{TEEP}=U \cdot \frac{G}{C_{P}}
$$

Where,

$$
\begin{aligned}
& \mathrm{U}=\text { Capacity Utilization } \\
& \mathrm{G}=\text { Demand over period } \\
& \mathrm{C}_{\mathrm{p}}=\text { Quantity of pieces that can be produced } \\
& \text { over planned loading time of bottleneck }
\end{aligned}
$$

Capacity Utilization $=\frac{\text { planned loading time }}{\text { total } \text { production time }}$

Planned loading time $=$ Total production time - shutdown losses (9)

\section{RESULTS AND DISCUSSION \\ Hour per Unit}

Hours per unit is a KPI used in measuring performance of assembly line. It translates Labour numbers, time essential to assemble a product and production volume. HPU is applied for bench marking for several work stations in assembly plant. HPU is used for essential business regions of assembly plant. This helps administration in making decisions when planning. It specifies labour numbers, production volume for a specified period, and time essential to assemble a car. Table 1 displays the labour numbers every month, working time expected every month, number of products manufactured in all of the six months, and the particular time it requires producing a product for every single month. From observation, it takes 155 hours to produce a product on average for the six months 
Table-1: Hour per unit

\begin{tabular}{|r|r|r|r|r|}
\hline Month & Labour(units) & EWT (hrs.) & Production Volume(units) & HPU(hrs/unit) \\
\hline July & 223 & 180 & 260 & 154.4 \\
\hline August & 220 & 180 & 255 & 155.3 \\
\hline September & 218 & 180 & 256 & 152.1 \\
\hline October & 221 & 180 & 249 & 159.8 \\
\hline November & 219 & 180 & 250 & 157.7 \\
\hline December & 225 & 180 & 264 & 153.41 \\
\hline Average & & & & 155 \\
\hline
\end{tabular}

\section{Organization Hour per Unit}

OHPU value is used for benchmarking for various work stations in an organization, as well as aid management in monitoring the performance of various work stations in assembly line. Labours hour performed by employees throughout every month of assembly operation is referred to as the actual operational hours.
This value is calculated for the whole line such as business areas. This is the calculated hour each month required in producing a unit car. The measurement and calculation are centred on essential business areas; this aids in translating labour hours required by the organization in building a vehicle.

Table-2: Organization Hour per Unit

\begin{tabular}{|r|r|r|r|}
\hline Month & Production Volume & Monthly time used ( hours) & OHPU(hrs/unit) \\
\hline July & $\mathbf{2 6 0}$ & $\mathbf{3 7 8 1 5 . 1 8}$ & $\mathbf{1 4 5 . 4 4}$ \\
\hline August & $\mathbf{2 5 5}$ & $\mathbf{3 7 8 2 8 . 2 8}$ & $\mathbf{1 4 8 . 3 5}$ \\
\hline September & $\mathbf{2 5 6}$ & $\mathbf{3 7 8 2 5 . 2 1}$ & $\mathbf{1 4 7 . 7 5}$ \\
\hline October & $\mathbf{2 4 9}$ & $\mathbf{3 7 8 2 6 . 3 0}$ & $\mathbf{1 5 1 . 9 1}$ \\
\hline November & $\mathbf{2 5 0}$ & $\mathbf{3 7 8 3 1 . 1 1}$ & $\mathbf{1 5 1 . 3 2}$ \\
\hline December & $\mathbf{2 6 4}$ & $\mathbf{3 7 8 2 0 . 2 7}$ & $\mathbf{1 4 3 . 2 6}$ \\
\hline
\end{tabular}

\section{Number of Material Handling Equipment for each Department}

The material handling equipment are machines used to transport material from one workstation to the other. Trolleys, Forklifts, Overhead crane, and Overhead conveyor system where the handling equipment's used to transport materials, parts, components and car frames from one work station to the other. 5 Trolleys, 3 forklifts and 3 Overhead cranes were the material equipment found in body shop. While 3 trolleys and 3 overhead cranes were the material equipment found in the paint shop. The trim chassis final makes use of 2 forklifts, 5 overhead Cranes and 3 Conveyor Systems.

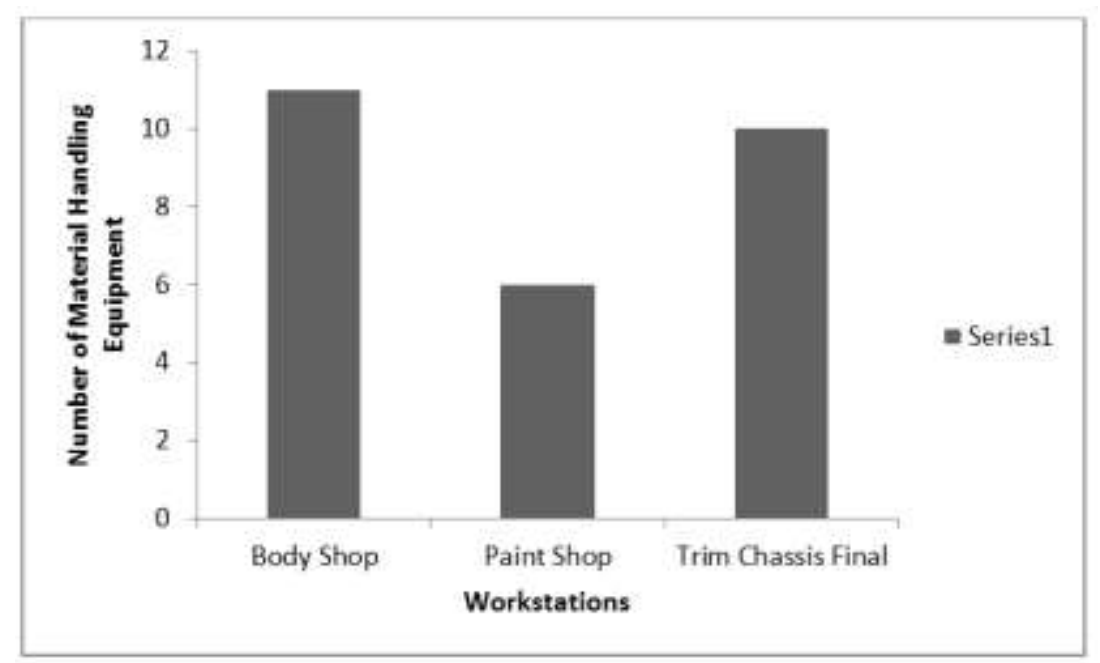

Fig-1: Material Handling Equipment

\section{Number of Equipment in Work Stations}

The figure below shows the number of automated, manual and semi-automated equipment used in numerous work stations in assembly plant. In the first major section, which is the body shop, there are 7 types of semi-automated, 8 types of manual and 5 types of automated equipment. The next section comprises of 4 types of manual and 5 types of automated equipment. The last department comprises of 6 types of semiautomated and 18 types of manual equipment. In the final section, no automation is performed. 


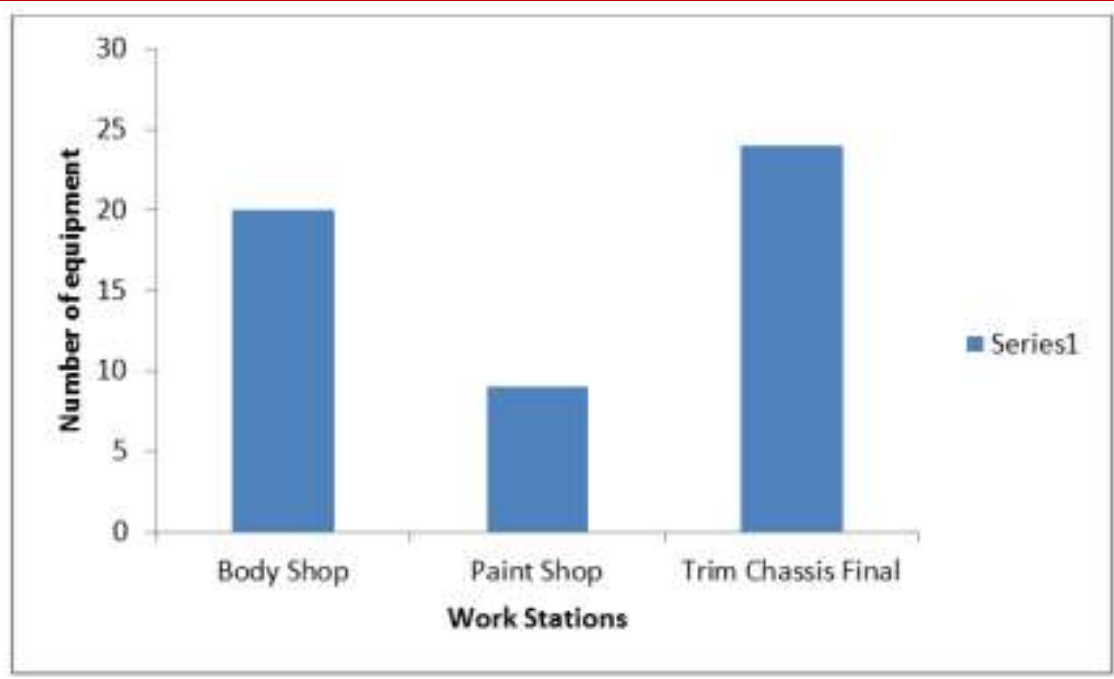

Fig-2: Number of Equipment

\section{Work Station Labour}

Figure-3 represents the number of workers in the Body Shop, Paint Shop and Trim Chassis Final. In the Body Shop section, we have 7 units Engineer, 44 Technicians and 7 helpers, which is 58 overall. The
Paint Shop comprises of 2 Engineers, 12 Technicians and 3 helpers, which gives you 17 as the sum. Furthermore, the final section comprises of 12 Engineers, 64 Technicians and 11 helpers, which is 87 overall.

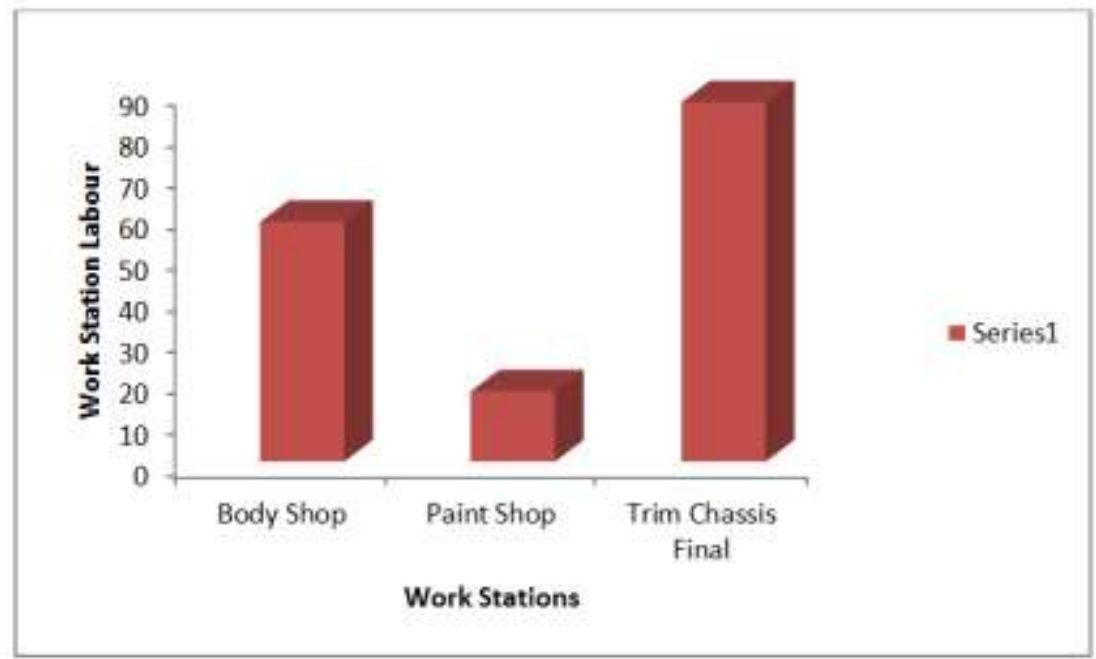

Fig-3: Workstation Labour

Total Effective Equipment Performance (TEEP)

TEEP shows just how much capacity is still waiting to be cracked in a secret plant. Furthermore, it displays exactly how much potential you need to improve the rate of production by using the current equipment you are making use of. The total effective equipment performance computed from Table-3 is $61.89 \%$. This implies that the plant utilization is not being maximized. Table- 4 shows the overall equipment effectiveness.

Table-3: Total Effective Equipment Performance

\begin{tabular}{|r|r|r|r|r|}
\hline Parameters & Machine P & Machine Q & Machine R & Assembly PQR \\
\hline Demand in pieces & 3600 & 2090 & 1600 & 7290 \\
\hline Total production time in hrs. & 45 & 45 & 45 & 45 \\
\hline Shutdown losses hrs. & 5 & 8 & 10 & 11 \\
\hline Capability in pieces & 4300 & 2650 & 1950 & 8900 \\
\hline TEEP & 0.7442 & 0.6485 & 0.6382 & 0.6189 \\
\hline TEEP in \% & $74.42 \%$ & $64.85 \%$ & $63.82 \%$ & $61.89 \%$ \\
\hline
\end{tabular}


Table-4: Data for overall equipment effectiveness

\begin{tabular}{|r|r|}
\hline Shift length & 540 minutes for one week \\
\hline Short breaks & 30 minutes \\
\hline Meal breaks & 30 minutes \\
\hline Down time & 300 minutes \\
\hline Ideal cycle time of production times & 2JPH \\
\hline Total output of operations & 68 vehicles \\
\hline Rejected products & 4 vehicles \\
\hline Planned production time & 2400 minutes \\
\hline Actual Production time & 2100 minutes \\
\hline
\end{tabular}

In order to achieve world-class overall equipment effectiveness and in order to reduce these losses, they have to be decrease in events which are explained in six big losses. Collapse of machines, unintended upkeep, lacking enough materials, lacking enough operators, and power failure are the leading events liable for losses in manufacturing operation.

It is vital to lessen these non-productive events affecting productivity of operation. This can be lessened by applying new tools and methods, such special purpose machinery, appropriate inventory storage, skilled labours, in line assembly, etc.

\section{CONCLUSION}

This study carried out automotive assembly process performance analysis for improved productivity. The analysis was performed at an automobile plant in Nigeria. The overall number of material handling systems and kinds of material handling systems were determined. The number of automated, manual and semi-automated equipment's used was also determined. The number of workers on the line were also determined. The labour productivity, hours per unit, organizational hour per unit, and TEEP were also determined. The following performance indices were gotten from our study.

The average production volume of automobile assembly line is 256 units for every month and its average on time delivery is $80.6 \%$. Nine hours was the time period the workers spent every day. 163 personnel with various skill sets were involved in the plant. The size of the plant is about $550,000 \mathrm{~m}^{2}$ and it housed offices, workstations, equipment's and operators. The body shop section comprises of 58 workers, whereas the paint shop section and trim chassis final section comprises of 18 and 87 workers respectively. In the trim chassis final, no automation is done. The operations are manual. The body shop segment and paint shop segment was ninety per cent automated. 8 trolleys, 5 forklifts, 11 Overhead cranes, 3 Overhead Conveyor systems were the material handling equipment's applied in assembly plant. The average hour per unit is 155 hours. The average organizational hour per unit is 148 hours i.e. it takes 148 hours to assemble the car. The total effective equipment performance is $61.89 \%$. This result shows that the plant is still under-utilized. It means that so much more can still be assembled in the plant. From the findings, it is recommended that more workers should be employed and predictive maintenance practises should be used to avoid collapse of machines in the assembly plant.

\section{REFERENCES}

1. Bisiriyu, R. (2012). New auto policy is ready. http://www.punchng.com

2. Ede, E. C., \& Chamberlin, O. (2013). History of Automobile Past and Present Challenges Facing Automobile Production in Nigeria. Journal of Research \& Method in Education, 2(4), 11-16. 